\title{
Pengetahuan Pedagogi Mahasiswa Calon Guru dalam Perencanaan Pengajaran Matematika dan Hubungannya dengan Keyakinan
}

\author{
Muhtarom \\ Program Studi Pendidikan Matematika, Universitas PGRI Semarang \\ muhtarom@upgris.ac.id
}

\begin{abstract}
Abstrak
Penelitian bertujuan untuk mendeskripsikan pengetahuan pedagogi mahasiswa calon guru dalam merancang pembelajaran matematika, serta hubungannya dengan keyakinan tentang pengajaran. Seorang mahasiswa calon guru berkeyakinan konstruktivis yang telah menyelesaikan matakuliah micro teaching serta mempunyai komunikasi baik yang ditunjukkan dari kelancaran dalam penyampaian gagasan dipilih menjadi partisipan penelitian. Pengambilan data dilakukan melalui teknik wawancara semi terstruktur. Data yang diperoleh dilakukan pengkodean, penyederhanaan, dipaparkan, dilakukan triangulasi waktu untuk mendapatkan data yang kredibel, kemudian ditarik kesimpulan. Hasil penelitian menunjukkan bahwa mahasiswa calon guru memiliki pengetahuan dalam penyusunan rencana pembelajaran dan media pembelajaran sesuai dengan kurikulum untuk memfasilitasi siswa belajar di kelas. Pemilihan representasi verbal, representasi simbol dan pemilihan masalah konstekstual sejalan dengan keyakinannya bahwa peran guru adalah membimbing siswa dan memfasilitasi siswa untuk aktif menemukan konsep matematika. Mahasiswa calon guru matematika memiliki pengetahuan yang baik tentang pemilihan waktu yang tepat untuk mengajukan pertanyaan kepada siswa. Partisipan mengetahui kapan harus bertanya, kapan harus melakukan refleksi terhadap jawaban siswa, dan kapan harus mengajukan pertanyaan baru atau memberikan tugas baru. Partisipan memiliki pengetahuan tentang teknik penilaian yaitu penilaian hasil belajar diperoleh dari cara siswa menemukan solusi masalah dan kesesuaian soal dengan penyelesaian yang dibuat oleh siswa.
\end{abstract}

Kata kunci: keyakinan, mahasiswa calon guru, pengetahuan pedagogi

\begin{abstract}
The purpose of this research is to describe the pedagogical knowledge of prospective teachers in designing mathematics learning and its relationship with beliefs about teaching. This research participant was a prospective teacher who was a constructivist belief that had taken a micro-teaching course and had excellent communication skills, as demonstrated by the fluency in delivering ideas. Data is collected through semistructured interview techniques. The data obtained were coded, simplified, presented, triangulated time for the credibility data, and concluded. The results show that prospective teachers knew in preparing lesson plans and learning media by the curriculum to facilitate students learning in class. The selection of verbal representations, symbol representations, and the selection of contextual problems is in line with his belief that the teacher's role is to guide students and help them discover mathematical concepts actively. Prospective teachers have good knowledge about choosing the right time to ask questions to students. Prospective teachers know when to ask questions, when to reflect on students' answers, and when to ask new questions or give new assignments. Prospective teachers know assessment techniques, namely the assessment of learning outcomes obtained from the way students find solutions to problems and the suitability of problems with solutions made by students.
\end{abstract}

Keywords: beliefs, prospective teacher, pedagogical knowledge 


\section{Pendahuluan}

Pedagogical Content Knowledge (PCK) merupakan integrasi pengetahuan konten dan pengetahuan pedagogi dalam bentuk cara penyajian dan perumusan pengetahuan konten (materi pelajaran) yang memudahkan siswa dalam memahaminya (Shulman, 1986). PCK merupakan menggambarkan gagasan yang dapat membangkitkan motivasi dan minat untuk mempelajari materi (Kwong et al, 2007). PCK sebagai kemampuan seorang guru dalam menggunakan pengetahuan matematika yang dimilikinya untuk mengajarkan materi matematika dalam berbagai cara sehingga siswa sukses dalam belajar (Gusnindar, Sutrisno, \& Syaiful, 2018; Lestari, Juniati, \& Suwarsono, 2018; Ma, 1999; Ma'rufi, Budayasa, \& Juniati, 2017; Muhtarom, Juniati, \& Siswono, 2019). Selanjutnya Black (2008) menjelaskan bahwa PCK mencakup beberapa kemampuan, yaitu: kemampuan guru menggunakan pengetahuan konten untuk menggunakan representasi yang berbeda, metode yang berbeda, membantu siswa membuat hubungan antara topik matematika, mampu mengidentifikasi kesalahan siswa, dan mampu mengajukan pertanyaan untuk membantu siswa memahami materi ajar.

Beberapa ahli seperti An, Kulm, dan Wu (2004), Ball, Thames, dan Phelps (2008), Guzel, (2010), Kilic (2011) Shulman (1986), serta Turnuklu dan Yesildere (2007) telah mengemukakan aspek-aspek pengetahuan PCK. Pengetahuan tentang isi, pengetahuan tentang pengajaran, dan pengetahuan tentang kurikulum merupakan komponen utama dalam PCK (An, Kulm, \& Wu, 2004; Turnuklu \& Yesildere, 2007). Penelitian di atas telah meletakkan dasar untuk pengembangan guru terkait komponen PCK yang menekankan pada tiga deskriptor, yaitu: content, pedagogy, dan student. Lebih lanjut An, Kulm, \& Wu (2004) menjelaskan pengetahuan tentang pengajaran merupakan komponen inti dari pengetahuan pedagogi. Peraturan Pemerintah Republik Indonesia Nomor 19 Tahun 2005 menguraikan kompetensi pedagogi merupakan kemampuan untuk mengelola pembelajaran siswa, yang terdiri dari: memahami siswa, merancang dan menerapkan pembelajaran, mengevaluasi hasil pembelajaran, dan mengembangkan siswa untuk mengaktualisasikan potensi mereka. Bagaimana proses pembelajaran berlangsung, apakah satu arah atau interaktif, berupa kegiatan eksploratif atau didominasi ceramah, berpusat pada siswa atau berpusat pada guru sangat bergantung dari perencanaan yang dilakukan. Ini berarti bahwa pengetahuan pedagogi sangat penting karena merupakan kompetensi pedagogi guru profesional.

Shulman (1986) menggambarkan pengetahuan pedagogi secara implisit sebagai kemampuan guru untuk mengubah pengetahuan kontennya menjadi representasi ide, ilustrasi, contoh, dan penjelasan dalam bentuk yang sangat pedagogi namun adaptif dengan 
mempertimbangkan keberagaman kemampuan siswa. Fennema dan Franke (1992) menjelaskan bahwa pengetahuan tentang pengajaran dan pengambilan keputusan memiliki efek pada keputusannya yang memengaruhi rencana dan tindakan mereka di kelas. Kilic (2011); Lestari, Juniati, dan Suwarsono (2018), serta Rowland, Huckstep, dan Thwaites (2005) menjelaskan bahwa pengetahuan pedagogi merupakan kemampuan dalam pengelolaan aktivitas pembelajaran siswa yang meliputi pengetahuan tentang manajemen kelas, tugas, perencanaan pembelajaran dan bagaimana siswa belajar. Guzel (2010); Harel dan Lim (2004); Kwong et al (2007), serta Muhtarom, Juniati, dan Siswono (2019) menegaskan bahwa pengetahuan pedagogi bergantung pada kemampuan dalam mentransformasikan materi melalui berbagai media pembelajaran sehingga memungkinkan siswa dapat memahaminya. Memiliki pengetahuan pedagogi berarti bahwa guru harus dapat mengevaluasi kelebihan dan kekurangan representasi yang digunakan untuk mengajarkan materi sesuai dengan kebutuhan siswa (Ball, Thames, \& Phelps, 2008; Kilic, 2011; Kwong et al, 2007). Selain itu, guru perlu memiliki pengetahuan untuk mengatur materi ajar, menggunakan contoh untuk memulai atau contoh untuk memperdalam pemahaman siswa (Ball, Thames, \& Phelps, 2008; Muhtarom, Juniati, \& Siswono, 2019).

Penelitian yang menguraikan komponen pengetahuan pedagogi dilakukan oleh Kilic (2011); Lestari, Juniati, dan Suwarsono (2018); Ma'rufi, Budayasa, dan Juniati (2017), serta Muhtarom, Juniati, dan Siswono (2019). Shulman (1986) menjelaskan bahwa pengetahuan tentang pedagogi mengacu pada kemampuan guru untuk memilih tugas, contoh, dan representasi serta strategi yang tepat untuk mengajar siswa. Kilic (2011) menjelaskan bahwa pengetahuan pedagogi merupakan kemampuan guru untuk memilih tugas, contoh, dan representasi yang tepat untuk sekelompok siswa tertentu dan strategi pengajaran mereka. Sedangkan Ma'rufi, Budayasa, dan Juniati (2017) menjelaskan bahwa pengetahuan tentang pedagogi terkait dengan perencanaan dan pengorganisasian pembelajaran, representasi yang akan digunakan, pemilihan contoh dan tugas, metode perencanaan, dan teknik evaluasi. Berdasarkan uraian di atas, sangat jelas bahwa pengetahuan tentang pedagogi memiliki komponen yang menekankan pada pengetahuan penyusunan rencana pelaksanaan, pengetahuan memilih representasi; pengetahuan memilih tugas matematika; pengetahuan pengajuan pertanyaan; dan pengetahuan teknik evaluasi. Lebih jelasnya, uraian dari deskripsi pengetahuan pedagogi disajikan dalam Tabel 1. 
Tabe1. Indikator pengetahuan pedagogi

\begin{tabular}{ll}
\hline \multicolumn{1}{c}{ Fokus Penelitian } & \multicolumn{1}{c}{ Deskipsi Indikator } \\
\hline $\begin{array}{l}\text { Penyusunan } \\
\text { rencana } \\
\text { pelaksanaan } \\
\text { pembelajaran }\end{array}$ & $\begin{array}{l}\text { Pemahaman dalam penyusunan rencana pelaksanaan pembelajaran } \\
\text { (RPP) }\end{array}$ \\
Memilih metode, dan media pembelajaran untuk mengajarkan materi \\
matematika \\
Memiliki pemahaman materi prasyarat untuk dapat mempelajari \\
materi.
\end{tabular}

(Ma'rufi, Budayasa, \& Juniati, 2017)

Penelitian-penelitian sebelumnya tentang pengetahuan pedagogi telah dilakukan oleh beberapa ahli. Misalnya, penelitian Ma'rufi, Budayasa, dan Juniati (2017) menjelaskan bahwa guru pemula cenderung memiliki pengetahuan pedagogi yaitu kurang variasi dalam penggunaan strategi pembelajaran, mengajukan pertanyaan yang monoton, tidak memanfaatkan potensi siswa, tidak memberikan ilustrasi, dan menjelaskan secara prosedural. Penelitian Lestari, Juniati, dan Suwarsono (2018) yang mengkaitkan literasi matematika menyimpulkan bahwa mahasiswa yang memiliki pengetahuan pedagogi yang baik dalam perencanaan pengajaran matematika tetapi ia kurang dalam penggunaan alat/media pembelajaran dan belum dapat menghubungkan pengetahuan prasyarat untuk mendukung literasi matematika. Sedangkan penelitian Belbase (2012) dan Muhtarom, Juniati, dan Siswono (2019) menunjukkan peran penting keyakinan dan PCK yang mempengaruhi pembelajaran. Kedua penelitian ini memberikan gambaran awal terkait peran keyakinan dalam pembelajaran matematika, tetapi belum detail menguraikan deskripsi pengetahuan pedagogi mahasiswa calon guru matematika yang dikaitkan dengan keyakinan mahasiswanya. Untuk alasan ini, keyakinan menjadi salah satu tinjauan dalam penelitian. 
Leder dan Forgasz (2002) menjelaskan bahwa keyakinan merupakan suatu pernyataan yang dikatakan atau dilakukan baik disadari ataupun tidak disadarinya. Lebih lanjut, Belbase (2012) menjelaskan bahwa keyakinan menyiratkan bagian dari 'persepsi' yang didasarkan pada asumsi, namun bagaimanapun juga keyakinan juga dapat didasarkan pada bagian yang dapat didefinisikan sebagai pengetahuan (pasti). Kemudian keyakinan yang didasarkan pada pengetahuan disebut sebagai nilai (value). Berdasarkan kajian di atas, maka penelitian ini bertujuan untuk mendeskripsikan pengetahuan pedagogi mahasiswa calon guru matematika dalam merancang pelaksanaan pembelajaran dan hubungannya dengan keyakinan tentang pengajaran.

Penelitian ini melaporkan hasil studi kasus mengenai peran pengetahuan pedagogi mahasiswa calon guru matematika dikaitkan dengan keyakinan untuk merancangkan pelaksanaan pembelajaran matematika. Peran pengetahuan pedagogi yang dijelaskan dalam penelitian ini berbeda dengan penelitian sebelumnya karena tidak hanya berfokus pada pengajaran matematika tetapi penelitian ini mengintegrasikan peran keyakinan dalam perancangan pelaksanaan pembelajaran matematika.

\section{Metode}

Tahap awal dalam pemilihan partisipan, peneliti memberikan angket untuk mengetahui keyakinan dari mahasiswa calon partisipan penelitian. Sebelum digunakan, angket telah divalidasi oleh tiga ahli dalam pendidikan matematika. Pengambilan data ini dilakukan secara bertahap terhadap seratus dua puluh empat mahasiswa semester 6 pada Perguruan Tinggi di Kota Semarang. Partisipan yang dipilih juga harus telah menempuh kuliah magang 2 (micro teaching) sehingga partisipan telah memiliki pengetahuan yang cukup terkait pembelajaran. Partisipan mempunyai kemampuan dalam menyampaikan gagasan baik secara lisan maupun tulisan. Pertimbangan lainnya dalam pemilihan partisipan adalah kemudahan komunikasi antara peneliti dengan calon partisipan. Hasilnya diperoleh mahasiswa calon guru yang memenuhi kriteria tersebut yaitu Miss Yeni (pseudo name). Yeni adalah mahasiswa sebuah Universitas di Kota Semarang Jawa Tengah dan etnis Jawa. Sebelum pelaksanaan penelitian ini, Yeni belum memiliki pengalaman mengajar di sekolah.

Hasil pemberian angket terhadap Miss Yeni diperoleh kesimpulan bahwa partisipan penelitian konsisten memiliki keyakinan konstruktivis sesuai pendapat Beswick (2012), Ernest (1989), Thompson (1992). Partisipan meyakini bahwa pembelajaran matematika harus berpusat pada siswa, serta guru sebagai fasilitator dalam pembelajaran. Soal non-rutin/masalah matematika diberikan oleh guru untuk diselesaikan oleh siswa dan jika siswa mengalami 
kesulitan maka guru memberikan scaffolding. Partisipan juga meyakini bahwa pemberian masalah matematika merupakan cara untuk memotivasi siswa dalam belajar matematika. Kajian kekonsistenan keyakinan merujuk pendapat Beswick (2012), Ernest (1989), Thompson (1992), Muhtarom, Juniati, dan Siswono (2017, 2018, 2019).

Data penelitian dikumpulkan peneliti dengan menggunakan pedoman wawancara pengukuran pengetahuan pedagogi. Sebelum digunakan, pedoman wawancara telah tervalidasi oleh tiga orang validator ahli dalam bidang pendidikan matematika dan hasilnya dinyatakan valid untuk dapat mengukur pengetahuan pedagogi mahasiswa calon guru matematika. Wawancara dilakukan sebanyak dua kali yaitu pada pada tanggal 30 Juli 2018 dan 6 Agustus 2018. Fokus penelitian dikembangkan dari aspek pengetahuan pedagogi yang dijelaskan oleh Kilic (2011); Lestari, Juniati, dan Suwarsono (2018); Ma'rufi, Budayasa, dan Juniati (2017); dan Muhtarom, Juniati, dan Siswono (2019). Uraian deskripsi pengetahuan pedagogi yang diungkap dalam penelitian ini meliputi: 1) pengetahuan penyusunan rencana pelaksanaan pembelajaran, tujuan, metode pembelajaran dan media pembelajaran, 2) pengetahuan memilih representasi, 3) pengetahuan memilih tugas matematika, 4) pengetahuan pengajuan pertanyaan, dan 5) pengetahuan teknik evaluasi.

Untuk memperoleh data penelitian yang kredibel, maka digunakan teknik triangulasi waktu dengan cara membandingkan data wawancara pertama dan data wawancara kedua. Hasil triangulasi menunjukkan bahwa terdapat keajegan data sehingga data penelitian yang diperoleh kredibel. Ini diperkuat dengan hasil analisis menggunakan software QSR NVivo 11 pada fitur sources cluster analysis yang didapatkan nilai korelasi Pearson sebesar 0,746715. Secara khusus, teknik analisis data menggunakan model alir yang terdiri tiga alur kegiatan secara bersamaan yaitu: reduksi data, penyajian data dan penarikan kesimpulan (Miles \& Huberman, 1992). Tiga kegiatan analisis data ini tidak bersifat hirarkis, tapi merupakan suatu jalinan kegiatan yang saling berinterasksi mulai dari sebelum, selama dan sesudah pengumpulan data. Untuk memperkuat analisis hubungan antar fokus penelitian pengetahuan pedagogi maka digunakan software QSR NVivo 11 untuk menunjukkan korelasinya sehingga dapat menggambarkan hubungan antar komponen dalam penelitian ini (Bazeley \& Jackson, 2013; Muhtarom, Murtianto, \& Sutrisno, 2017).

\section{Hasil Penelitian}

\section{Penyusunan Rencana Pelaksanaan Pembelajaran}

Yeni menyusun rencana pelaksanaan pembelajaran (RPP) berdasarkan keyakinannya yang sesuai dengan kurikulum K-13 bahwa pembelajaran matematika harus memfasilitasi 
siswa untuk mengkontruksi pengetahuannya sendiri. Untuk mendukung tercapainya tujuan pembelajaran, digunakan metode diskusi dan tanya jawab. Metode diskusi sebagai sarana siswa bertukar pikiran dan saling memberikan informasi antar siswa. Sedangkan tanya jawab digunakan untuk membantu siswa yang tidak memahami materi sehingga pemahaman siswa bertambah. Misalnya dalam kegiatan inti diberikan rangsangan untuk mengarahkan siswa ke materi, memberikan masalah, pertanyaan, data collecting, mengolah data, dan menyelesaikan masalah. Yeni membuat media pembelajaran berupa power point yang memuat konsep materi dan penyelesaian masalah SPLDV. Ini selaras dengan keyakinan Yeni yang meyakini bahwa pendekatan yang layak digunakan dalam pembelajaran matematika adalah berpusat pada siswa. Partisipan memahami bahwa pengetahuan prasyarat untuk mempelajari SPLDV adalah operasi aljabar dan materi persamaan linier satu variabel (PLSV) meliputi koefisien, variabel, konstanta, dan cara mencari nilai variabel dalam PLSV. Berikut ini adalah kutipan hasil wawancara partisipan.

Peneliti : : Komponen apa saja yang ada dalam RPP yang Saudara buat?

Partisipan : Identitas sekolah, kompetensi inti, kompetensi dasar, indikator pencapaian kompetensi, tujuan pembelajaran, materi pembelajaran, sumber belajar, pendekatan, model, metode, kegiatan pembelajaran, dan instrumen penilaian meliputi instrumen sikap, tes tertulis dan kisi-kisi tes tertulis dalam bentuk essay.

Peneliti : RPP ini dibuat berdasarkan apa?

Partisipan $\quad$ : Saya membuat sendiri berdasarkan keyakinan saya yang sejalan dengan kurikulum K-13.

Peneliti : : Apa tujuan yang hendak dicapai dari kegiatan pembelajaran?

Partisipan : Melalui model discovery learning dan pendekatan scientific siswa terlebih dahulu mengamati melalui kegiatan membaca supaya siswa dapat menginterpretasikan persamaan dan sistem persamaan linier dua variabel, siswa dapat menyelesaikan masalah kontekstual yang berkaitan dengan SPLDV terkait kehidupan sehari-hari melalui penanaman karakter rasa ingin tahu, jujur, dan tanggung jawab, serta pengembangan kemampuan berpikir kritis, komunikasi dan kerjasama.

Peneliti : Metode yang digunakan?

Partisipan : Diskusi kelompok dan tanya jawab. Diskusi dalam rangka untuk menyelesaikan masalah yang saya berikan, sedangkan tanya jawab digunakan misalnya ketika siswa tidak paham. Melalui diskusi siswa dapat bertukar pikiran pemahamannya, memberikan informasi satu sama lainnya. Sedangkan melalui tanya jawab siswa menjadi paham, kemudian akan muncul pertanyaan baru sehingga pemahamannya menjadi bertambah.

Peneliti : : Apakah Saudara juga akan membuat media pembelajaran?

Partisipan : Iya saya membuat power point yang isinya bukan materi pelajaran, tetapi hanya point-point utama dari apa yang akan saya sampaikan. Urutan materinya adalah judul materi, point-point materi, perbedaan PLDV, SPLDV dan penyelesaian masalah SPLDV.

Peneliti : Apa yang mendasari Saudara dalam pemilihan metode, model discovery learning, dan urutan materi pada media pembelajaran?

Partisipan : Keyakinan saya bahwa dengan metode dan model discovery learning maka siswa akan berpikir lebih kritis, siswa menemukan konsep sendiri.

Peneliti : Pengetahuan prasyarat apa saja yang harus dimiliki siswa untuk dapat mempelajari materi SPLDV?

Partisipan $\quad$ : Yang penting adalah materi persamaan linier satu variabel yang sudah dipelajari di kelas VII dan perhitungan aljabar. Jadi dalam SPLV siswa sudah mengetahui siswa tentang koefisien, variabel, konstanta, dan cara mencari nilai variabel. Kemudian untuk operasi aljabar karena di dalam penyelesaian SPLDV menggunakan operasi aljabar. 


\section{Memilih Representasi}

Partisipan Yeni memilih representasi untuk mendukung keyakinannya bahwa peran seorang guru adalah membimbing siswa, memfasilitasi siswa untuk berperan aktif menemukan konsep/rumus matematika. Partisipan memilih menggunakan representasi verbal dan representasi simbol. Representasi simbol dipilih dengan menggunakan simbol x dan y karena masih banyak siswa yang menggunakan representasi simbol dalam penyelesaian masalah. Yeni menggunakan representasi verbal untuk menekankan kebenaran dalam matematika, misalnya menekankan kata-kata kunci sehingga siswa dapat memahaminya. Menekankan secara verbal saat operasi aljabar yaitu ketika tanda dari koefisien sama maka dikurangi dan ketika tanda dari koefisien berbeda maka dijumlahkan. Berikut ini adalah kutipan hasil wawancara partisipan.

Peneliti : Representasi apa yang Saudara gunakan? Alasannya?

Partisipan : Menggunakan representasi simbol seperti $x$, y karena siswa menggunakannya di SPLDV sebagai variabel. Representasi verbal digunakan untuk menekankan kebenaran dalam matematika. Misalnya untuk soal cerita saya menekankan kata kunci seperti selisih maknanya dikurangi, jumlah itu maknanya ditambah. Saya juga akan menekankan secara verbal saat operasi aljabar yaitu ketika tanda dari koefisien sama maka dikurangi dan ketika tanda dari koefisien berbeda maka dijumlahkan.

\section{Memilih Tugas Matematika}

Yeni menegaskan bahwa dalam perencanaan pembelajaran, dia tidak memberikan contoh soal tetapi memberikan masalah kontekstual dengan mempertimbangkan pemahaman siswa. Masalah yang diberikan merupakan soal non-rutin. Tujuan pemberian soal adalah membantu siswa menyelesaikan masalah yang diberikan dengan caranya sendiri untuk menemukan solusi/konsep matematika dan untuk melatih siswa untuk aktif berinteraksi dengan siswa lainnya. Agar siswa lebih memahami materi, Yeni menegaskan akan menugaskan siswa untuk membuat soal dan penyelesaiannya. Berikut ini adalah kutipan hasil wawancara partisipan.

\footnotetext{
Peneliti : : Apakah Saudara akan memberi contoh soal atau tidak? Berikan alasannya!

Partisipan : Tidak. Dalam pembelajaran saya akan langsung memberikan masalah ke siswa karena model discovery learning mendorong siswa untuk mengkonstruksi konsep matematika. Jadi saya tidak ingin memberikan contoh, tetapi siswa mengerjakan masalah yang diberikan dengan caranya sendiri untuk menemukan solusi/konsep.

Peneliti : Masalahnya dalam bentuk seperti apa?

Partisipan : Saya menggunakan soal kontekstual dalam kehidupan sehari-hari. Diketuhui:

$3 \mathrm{~kg}$ apel $+2 \mathrm{~kg}$ jeruk $=65.000$

$2 \mathrm{~kg}$ apel $+3 \mathrm{~kg}$ jeruk $=60.000$

Lebih mahal manakah antara apel dengan jeruk? Mengapa?

Berapakah harga $1 \mathrm{~kg}$ apel dan $1 \mathrm{~kg}$ jeruk?

Berapakah harga $5 \mathrm{~kg}$ apel dan $6 \mathrm{~kg}$ jeruk?

Peneliti : : Apakah siswa sudah pernah menyelesaikan masalah yang akan Saudara berikan?

Partisipan : Menurut saya belum karena ini pertama saya akan mengajar materi SPLDV di kelas tersebut. Soal saya buat berbeda dengan soal dibuku dan siswa diberi kebebasan menyelesaikan masalah tersebut menggunakan pemikiran mereka maupun dengan cara yang ada di buku.
} 


\section{Pengajuan Pertanyaan}

Partisipan Yeni merancang mengajukan pertanyaan klarifikasi untuk meminta penjelasan dari jawaban siswa dan mengajukan pertanyaan baru ketika siswa dapat memberikan solusi yang ditemukan. Ketika siswa kesulitan menjawab pertanyaan guru, Yeni akan memberikan kesempatan kepada siswa lain untuk menjawab dan mengajukan pertanyaan lain yang lebih mudah tetapi mempunyai tujuan yang sama. Pertanyaan yang diberikan dengan mempertimbangkan kedalaman materi dan pemahaman siswa. Ini sejalan dengan keyakinan partisipan yang meyakini bahwa scaffolding diberikan kepada siswa ketika mengalami kesulitan belajar. Berikut ini adalah kutipan hasil wawancara partisipan.

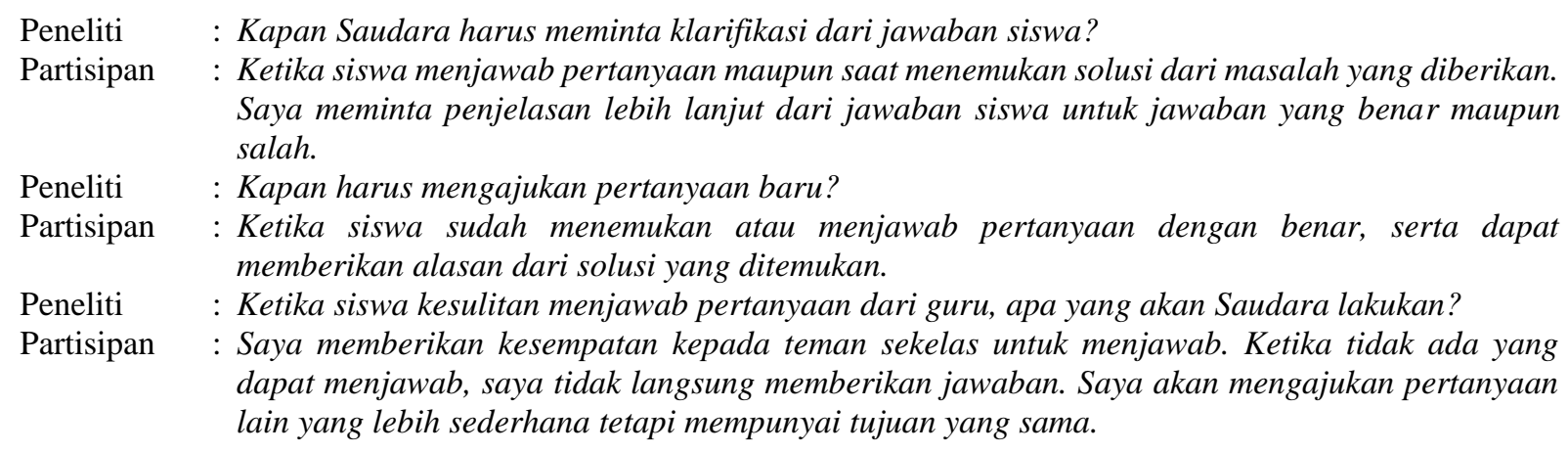

\section{Teknik Evaluasi}

Yeni menjelaskan bahwa penilaian aspek sikap dilakukan dengan memperhatikan keaktifan siswa, kejujuran siswa, tanggungjawab dalam menyelesaikan soal. Sesuai keyakinan Yeni maka jawaban dari masalah tersebut digunakan untuk penilaian aspek pengetahuan. Penilaian juga diperoleh terhadap kemampuan siswa dalam membuat soal dan jawabannya. Setiap siswa yang mempresentasikan hasil pekerjaannya di papan tulis akan mendapatkan penghargaan berupa poin tambahan sehingga siswa semangat belajar. Yeni menjelaskan bahwa penilaian hasil belajar siswa didasarkan pada cara siswa menemukan solusi dari masalah, dan kesesuaian soal yang dibuat oleh siswa dengan penyelesaiannya. Berikut ini adalah kutipan hasil wawancara partisipan.

\footnotetext{
Peneliti : : Apakah instrumen penilaian di jelaskan dalam RPP?

Partisipan : Instrumen penilaian sikap untuk menilai keaktifan siswa dalam pembelajaran, misalnya keaktifan, jujur, bertanggungjawab. Penilaian tes tertulis untuk mengukur pengetahuan siswa dalam memahami materi, kemudian juga instrumen tugas untuk membuat soal dan penyelesaiannya sehingga dapat mengukur aspek pengetahuan dan keterampilan.

Peneliti : Bagaimana Saudara memberikan penghargaan kepada siswa?

Partisipan : Memberikan point penambahan nilai ketika siswa sudah menemukan solusi dari masalah sehingga siswa lebih semangat.

Peneliti : : Apakah Saudara tetap menghargai jawaban siswa yang tidak sama di buku?

Partisipan : Saya memberi kebebasan kepada siswa untuk mencari dan menyelesaikan masalah dengan caranya sendiri. Mereka bebas menggunakan cara apapun, tidak harus sama dengan buku maupun dengan cara yang saya harapkan.
}

Peneliti : : Bagaimana menilai hasil belajar siswa sesuai dengan kompetensi yang dicapai? 
Partisipan : Cara siswa menemukan solusi masalah, dan kesesuaian soal yang dibuat oleh siswa dengan penyelesaiannya.

Peneliti : : Apa yang mendasari Saudara dalam membuat RPP?

Partisipan : Saya membuat RPP berdasarkan keyakinan yang saya miliki. Misalnya penggunaan metode tanya jawab dan diskusi karena saya meyakini bahwa pembelajaran matematika harus students center. Peran guru tidak menjelaskan tetapi sebagai fasilitator pembelajaran dan tidak langsung memberikan jawaban ketika siswa melakukan kesalahan maupun kesulitan. Melalui diskusi dan tanya jawab diharapkan siswa memahami konsep dan akhirnya siswa mengkonstruksi pengetahuannya sendiri. Kemudian pemberian masalah kontekstual dan siswa membuat soal matematika juga didasarkan pada keyakinan saya untuk memotivasi siswa dalam belajar.

\section{Pembahasan}

Hasil penelitian menunjukkan bahwa mahasiswa calon guru matematika menyadari pentingnya perencanaan dan media pembelajaran untuk memfasilitasi siswa belajar di kelas. Ini konsisten dengan pendapat Lestari, Juniati, dan Suwarsono (2018), dan Rowland, Huckstep, dan Thwaites (2005) yang menjelaskan bahwa pengetahuan pedagogi berkaitan dengan kemampuan perencanaan pembelajaran dan manajemen kelas untuk memfasilitasi peserta didik belajar matematika. Guzel (2010); Harel dan Lim (2004); Kwong et al (2007); Muhtarom, Juniati, dan Siswono (2019) menegaskan bahwa pengetahuan pedagogi bergantung pada kemampuan guru dalam mentransformasikan materi melalui berbagai media pembelajaran sehingga memungkinkan siswa dapat memahaminya. Pemahaman mahasiswa calon guru matematika tentang materi prasyarat dan tujuan pembelajaran berdampak pada pengambilan keputusan dalam pemilihan metode, dan media pembelajaran. Ini sejalan dengan keyakinan partisipan yang meyakini bahwa pendekatan yang layak digunakan dalam pembelajaran matematika adalah berpusat pada siswa. Pembelajaran dimulai dengan memberikan masalah kepada siswa (Barkatsas \& Malone, 2005; Thompson, 1992), membimbing siswa, berdiskusi untuk mengeksplorasi pengetahuan dan menemukan penyelesaian (Felbrich, Müller, \& Blömeke, 2008; Felbrich, Kaiser, \& Schmotz, 2012; Stipek, Givvin, Salmon, \& MacGyvers, 2001).

Partisipan menggunakan representasi verbal dan representasi simbol. Representasi simbol dipilih dengan menggunakan simbol $\mathrm{x}$ dan y karena masih banyak siswa yang menggunakan representasi simbol dalam penyelesaian masalah. Fakta bahwa siswa seringkali menggunakan representasi simbolik terkait prosedur penyelesaian masalah matematika, tidak terkecuali pada materi sistem persamaan linier dua variabel dipengaruhi oleh kebiasaan guru dikelas (Nizaruddin, Muhtarom, \& Murtianto, 2017; Muhtarom, Juniati, \& Siswono, 2019). Black (2008) juga menjelaskan bahwa pengetahuan prosedural yang menggunakan representasi simbol sangat dominan dalam praktik instruksional pengajaran di kelas dibandingkan representasi lainnya. Penggunaan representasi ini untuk mendukung metode tanya jawab dan 
metode diskusi, serta media pembelajaran. Ini sejalan dengan Ball, Thames, dan Phelps (2008); Kilic (2011); Kwong et al (2007) yang menyatakan bahwa kemampuan guru untuk memilih representasi dan mengevaluasi kelebihan dan kekurangan representasi yang digunakan untuk mengajarkan konten matematika sesuai dengan kebutuhan siswa.

Partisipan memberikan soal non-rutin untuk menumbuhkan interaksi antar siswa. Ini sejalan dengan pendapat Ma'rufi, Budayasa, dan Juniati (2017) bahwa guru harus dapat menyajikan konten dengan berbagai cara seperti; masalah masalah kontekstual atau gambar. Kilic (2011) menegaskan bahwa pengetahuan pedagogi merupakan kemampuan guru untuk memilih tugas, contoh, dan representasi yang tepat untuk sekelompok siswa tertentu dan strategi pengajaran mereka. Guru perlu memiliki pengetahuan untuk mengatur konten matematika, menggunakan contoh untuk memulai atau contoh untuk memperdalam pemahaman siswa (Ball, Thames, \& Phelps, 2008; Muhtarom, Juniati, \& Siswono, 2019). Partisipan telah menunjukkan cara memotivasi siswa yaitu melalui pemberian masalah matematika yang menantang. Ini sejalan dengan keyakinan partisipan bahwa guru harus memberikan soal non-rutin untuk diselesaikan oleh siswa. Stipek, Givvin, Salmon, dan MacGyvers (2001) menyatakan bahwa guru berkeyakinan konstruktivis menggunakan strategi memotivasi didasarkan pada substansial kualitas seperti termuatnya tantangan dari tugas matematika.

Partisipan memfasilitasi dan memandu siswa daripada menyediakan jawaban dan penjelasan, menilai pemahaman siswa, menghargai dan mendorong siswa untuk mengkonstruk pengetahuan, mengontrol kelas. Partisipan tahu kapan harus bertanya, kapan harus menggunakan jawaban siswa untuk menghasilkan ide matematika, dan kapan harus mengajukan pertanyaan baru atau untuk memberikan tugas baru untuk melanjutkan pembelajaran. Pengetahuan partisipan tentang pengajuan pertanyaan sejalan pendapat Black (2008); Turnuklu dan Yesildere (2007) yang menjelaskan bahwa guru harus mampu memahami kesulitan siswa, memahami alasan kesulitan siswa dan mampu mengajukan pertanyaan yang tepat dan bermakna untuk memahami proses berpikir mereka. Bahkan Kilic (2011) menegaskan pengetahuan konten dan siswa adalah faktor penentu keberhasilan seorang guru dalam penguasaan kelas dan menjawab pertanyaan siswa. Lebih lanjut Karahasan (2010) menjelaskan bahwa peran guru adalah mendiagnosis kesalahan siswa dan menunjukkan kesulitan siswa, memandu dan memfasilitasi siswa daripada menyediakan jawaban, penjelasan, dan menyadari kebutuhan siswa.

Partisipan memiliki pengetahuan dalam penilaian proses dan hasil belajar. Dijelaskan dalam Peraturan Pemerintah Republik Indonesia Nomor 19 Tahun 2005 bahwa mengevaluasi 
hasil pembelajaran merupakan salah satu kompetensi pedagogi yang harus dimiliki oleh guru. Turnuklu dan Yesildere (2007) guru yang baik mampu untuk membuat kriteria penilaian yang sesuai dan mampu melakukan penilaian jawaban siswa sesuai kriteria yang dibuat. Lebih lanjut Kwong et al (2007); Muhtarom, Juniati, dan Siswono (2019) menjelaskan bahwa perlu memahami dan mengambil tindakan yang tepat untuk mengatasi kesulitan belajar dan kesalahan siswa melalui berbagai teknik evaluasi yang tepat. Guru dapat memilih pendekatan yang sesuai untuk pembelajaran, dan memutuskan teknik penilaian yang tepat untuk digunakan dalam kegiatan pembelajaran. Pemahaman terhadap pengetahuan pedagogi membantu guru untuk merefleksikan pembelajaran mereka (Ma'rufi, Budayasa, \& Juniati, 2017) dan meningkatkan interaksi efektif antara siswa dan guru (Nizaruddin, Muhtarom, \& Zuhri, 2019).

Uraian di atas didukung dengan korelasi positif antar setiap komponen pengetahuan pedagogi yang dianalisis dengan menggunakan software QSR NVivo 11. Hasil analisis didapatkan bahwa terdapat hubungan kuat antara pengetahuan penyusunan rencana pembelajaran dan pengetahuan pemilihan tugas matematika yang ditunjukkan dengan koefisien korelasi sebesar 0,786; korelasi cukup kuat antara penyusunan rencana pembelajaran dan pengetahuan teknik evaluasi yang ditunjukkkan dengan koefisien korelasi sebesar 0,760; korelasi kuat antara pengetahuan pemilihan tugas matematika dan pengetahuan teknik evaluasi yang ditunjukkkan dengan koefisien korelasi sebesar 0,834; dan korelasi kuat antara pengetahuan pengajuan pertanyaan dan pengetahuan pemilihan tugas matematika yang ditunjukkkan dengan koefisien korelasi sebesar 0,619. Sedangkan untuk hubungan antara pengajuan pertanyaan dan pengetahuan pemilihan representasi diperoleh korelasi cukup kuat yang ditunjukkan dengan koefisien korelasi sebesar 0,492 dan korelasi cukup kuat antara pengetahuan pemilihan representasi dan pengetahuan teknik evaluasi yang ditunjukkkan dengan koefisien korelasi sebesar 0,506.

Hasil penelitian menunjukkan bahwa pengetahuan pedagogi yang dijelaskan dalam penelitian ini berbeda dengan penelitian sebelumnya karena mengintegrasikan peran keyakinan dalam perancangan pelaksanaan pembelajaran matematika. Hasil ini sejalan penelitian sebelumnya yaitu Belbase (2012), dan Muhtarom, Juniati, dan Siswono (2019) yang menjelaskan peran penting keyakinan dan PCK dalam pembelajaran matematika. Namun demikian, hasil penelitian ini berbeda dengan hasil penelitian Ma'rufi, Budayasa, dan Juniati (2017), dan Lestari, Juniati, dan Suwarsono (2018). Temuan penelitian ini menunjukkan bahwa mahasiswa calon guru yang belum memiliki pengalaman mengajar memiliki pengetahuan pedagogi yang baik dalam penggunaan strategi pembelajaran, penggunaan media pembelajaran, pengajuan pertanyaan yang bervariasi, mampu memanfaatkan potensi siswa dalam membuat 
dan menyelesaikan soal matematika, dan memiliki pengetahuan dalam teknik penilaian. Hal ini dapat disebabkan karena mahasiswa calon guru matematika sebagai partisipan dalam penelitian ini konsisten memiliki keyakinan konstruktivis. Selanjutnya perlu dikembangkan penelitian dengan partisipan mahasiswa calon guru yang memiliki keyakinan yang berbeda serta pengaruhnya terhadap pengetahuan pedagogi mereka.

\section{Simpulan}

Temuan penelitian menunjukkan peran penting pengetahuan pedagogi dalam perancangan pembelajaran dan hubungannya dengan keyakinan tentang pengajaran. Mahasiswa calon guru matematika memiliki pengetahuan dalam penyusunan rencana pembelajaan, pemilihan representasi, pemberian tugas matematika, pengajuan pertanyaan, dan teknik penilaian/evaluasi. Hasil penelitian ini dapat digunakan sebagai masukan untuk lembaga Pendidikan Guru Matematika untuk mengintegrasikan filosofi keyakinan dan penguatan kemampuan PCK mahasiswa, sehingga terjadi integrasi antara keyakinan dan pengetahuan untuk pengajaran matematika. Berikutnya akan diuraikan perbedaan pengetahuan pedagogi dari tiga mahasiswa calon guru berkemampuan matematika yang sama dan bagaimana keyakinan dapat menyebabkan perbedaan tersebut.

\section{Referensi}

An, S., Kulm, G., \& Wu, Z. (2004). The pedagogical content knowledge of middle school, mathematics teachers in China and the US. Journal of Mathematics Teacher Education, 7(2), 145-172. https://doi.org/10.1023/B:JMTE.0000021943.35739.1c.

Ball, D. L., Thames, M. H., \& Phelps, G. (2008). Content knowledge for teaching: What makes it special? Journal of Teacher Education, 59(5), 389-407. https://doi.org/10.1177/0022487108324554.

Barkatsas, A. T., \& Malone, J. (2005). A typology of mathematics teachers' beliefs about teaching and learning mathematics and instructional practices. Mathematics Education Research Journal, 17(2), 69-90. https://doi.org/10.1007/BF03217416.

Bazeley, P. \& Jackson, K. (2013). Qualitative data analysis with NVivo. Los Angeles: Sage Publications.

Belbase, S. (2012). Teacher belief, knowledge, and practice: A trichotomy of mathematics teacher education. Retrieved from http://files.eric.ed.gov /fulltext/ED530017.pdf.

Beswick, K. (2012). Teachers' beliefs about school mathematics and mathematicians' mathematics and their relationship to practice. Educational Studies in Mathematics, 79, 127-147. https://doi.org/10.1007/s10649-011-9333-2.

Black, J. W. (2008). Content knowledge and pedagogical content knowledge of algebra teachers and changes in both types of knowledge as a result of professional development. Proceedings of the 5th Annual TEAM-Math Partnership Conference Pre-Session (pp. 3040). New York, The Association of Public and Land-grant Universities. 
Ernest, P. (1989). The impact of beliefs on the teaching of mathematics. in Bloomfield, A. and Harries, T. Eds (1994) Teaching and Learning Mathematics, Derby, Association of Teachers of Mathematics.

Fennema, E., \& Franke, M. (1992). Teacher's knowledged and its impact. In Grouws D. A. (Ed.) Handbook of research on mathematics teaching and learning (p.147-164). New York, Macmillan Publishing Company.

Felbrich, A., Kaiser, G., \& Schmotz, C. (2012). The cultural dimension of beliefs: An investigation of future primary teachers' epistemological beliefs concerning the nature of mathematics in 15 countries. ZDM Mathematics Education, 44(3), 355-366. https://doi.org/10.1007/s11858-012-0418-x.

Felbrich, A., Müller, C., \& Blömeke, S. (2008). Epistemological beliefs concerning the nature of mathematics among teacher educators and teacher education students in mathematics. ZDM Mathematics $\quad$ Education, 40(5), https://doi.org/10.1007/s11858-008-0153-5.

Gusnindar, G., Sutrisno, S., \& Syaiful, S. (2018). Pengembangan perangkat pembelajaran matematika berdasarkan kerangka kerja TPACK pada materi lingkaran untuk mengoptimalkan kemampuan penalaran deduktif. AKSIOMA: Jurnal Program Studi Pendidikan Matematika, 7(3), 403-412. https://doi.org/10.24127/ajpm.v7i3.1557.

Guzel, E. B. (2010). An investigation of pre-service mathematics teachers' pedagogical content knowledge, using solid object. Journal Scientific Research and Essay, 5(14), 187-1880.

Harel, G., \& Lim, H.K. (2004). Mathematics teacher knowledge based: Preliminary result. In marit, J.H., and Anne, B.F. (eds). Proccedings of the 28th Conferrence of the International Group for the Phycology of Mathematics Education (vol 3, 25-32). Bergen, Norway: Bergen University College.

Karahasan, B. (2010). Pre-service secondary mathematics teachers' pedagogical content knowledge of composite and inverse functions. Turki: Secondary Science and Mathematics Education Department, Middle East Technical University.

Kilic, H. (2011). The nature of pre-service teachers' pedagogical content knowledge. Proceedings of the Seventh Congress of the European Society for Research in Mathematics Education-CERME7 (pp. 2690-2696). Rzeszów, University of Rzeszów.

Kwong, C. W., Joseph, Y. K. K., Eric, C. C. M., Khoh, L. T. S., Gek, C. K., \& Eng, N. L. (2007). Development of mathematics pedagogical content knowledge in student teachers. The Mathematics Educator, 10(2), 27-54.

Leder, G. C., \& Forgasz, H. J. (2002). Measuring mathematical belief and their impact on the learning of mathematics: A new approach. In G. C.Leider, E. Pehkonen, dan G. Torner (ed). Beliefs: A hidden variable in mathematics education?. Dordrecht: Kluwer Academic Publisher. https://doi.org/10.1007/0-306-47958-3.

Lestari, N. D. S., Juniati, D., \& Suwarsono, S.T. (2018). Exploring the Knowledge of Content and Teaching (KCT) of prospective math teacher in planning mathematical literacy teaching. Conference Proceedings The 5th International Conference on Research, Implementation, \& Education of Mathematics and Sciences. NewYork, IOP Publishing. https://doi.org/10.1088/1742-6596/1097/1/012150.

Ma, L. (1999). Knowing and teaching elementary mathematics: Teachers' understanding of fundamental mathematics in China and the United States. Mahwah, NJ: Lawrence Erlbaum Associates.

Ma'rufi, M., Budayasa, I. K., \& Juniati, D. (2017). Pedagogical content knowledge: Knowledge of pedagogy novice teachers in mathematics learning on limit algebraic function. Conference Proceedings International Conference on Mathematics, Science, and Computer Science (ICMSC) 2016. College Park: AIP Publishing. https://doi.org/10.1063/1.4975975. 
Miles, M. \& Huberman, A. M. (1992). Analisis data kualitatif: Buku sumber tentang metodemetode baru. Jakarta: UI Press.

Muhtarom, M., Juniati, D., \& Siswono, T. Y. E. (2017). Consistency and inconsistency of prospective teachers' beliefs in mathematics, teaching, learning and problem solving. Conference Proceeding The 4th International Conference on Research, Implementation, and Education of Mathematics and Science (4th ICRIEMS). College Park: AIP Publishing. https://doi.org/10.1063/1.4995141.

Muhtarom, M., Juniati, D., \& Siswono, T. Y. E. (2018). Exploring prospective teachers' beliefs about nature of mathematics. Journal of Engineering and Applied Sciences, 13(10), 35473554.

Muhtarom, M., Juniati, D., \& Siswono, T. Y. E. (2019). Examining prospective teacher beliefs and pedagogical content knowledge towards teaching practice in mathematics class: a case study. Journal on Mathematics Education, 10(2), 185-202. https://doi.org/10.22342/jme.10.2.7326.185-202.

Muhtarom, M., Murtianto, Y. H., \& Sutrisno, S. (2017). Thinking process of students with highmathematics ability (A study on QSR NVivo 11-assisted data analysis). International Journal of Applied Engineering Research, 12(17), 6934-6940.

Nizaruddin, N., Muhtarom, M., \& Murtianto, Y. H. (2017). Exploring of multi mathematical representation capability in problem solving on senior high school students. Problems of Education in the 21st Century, 75(6), 591-598.

Nizaruddin, N., Muhtarom, M., \& Zuhri, M. S. (2019). Improving mechanical engineering students' achievement in calculus through problem-based learning. Universal Journal of Educational Research 7(12), 2729-2733. https://doi.org/10.13189/ujer.2019.071221.

Peraturan Pemerintah Republik Indonesia Nomor 19 tentang Standar Nasional Pendidikan. (2005). Jakarta: Kemdikbud.

Rowland, T., Huckstep, P., \& Thwaites, A. (2005). Elementary teachers' mathematics subject knowledge: The knowledge quartet and the case of Naomi. Journal of Mathematics Teacher Education, 8(3), 255-281. https://doi.org/10.1007/s10857-005-0853-5.

Shulman, L. S. (1986). Those who understand: Knowledge growth in teaching. Educational Researcher, 15(2), 4-14. https://doi.org/10.3102/0013189X015002004.

Stipek, D. J., Givvin, K. B., Salmon, J. M., \& MacGyvers, V. L. (2001). Teachers' beliefs and practices related to mathematics instruction. Teaching and Teacher Education, 17(2), 213-226. https://doi.org/10.1016/S0742-051X(00)00052-4.

Thompson, A. G. (1992). Teachers' beliefs and conceptions: A synthesis of the research. In D. A. Grouws (Ed.), Handbook of research on mathematics teaching and learning (pp. 127146). Reston, VA: National Council of Teachers of Mathematics.

Turnuklu, E. B., \& Yesildere, S. (2007). The pedagogical content knowledge in mathematics: Pre-service primary mathematics teachers' perspectives in Turkey. Issues in the Undergraduate Mathematics Preparation of School Teachers: The Journal, 1(2), 1-13. 